\section{Identical strangers}

\author{
John Launer
}

Jim Lewis and Jim Springer lived in different towns in Ohio in the USA, 40 miles apart. So far as they were aware, they had never met, but they each knew they had been born with an identical twin, and had then been adopted by different families. In his late 30s, Jim Lewis decided to track down his lost brother, who turned out to be Jim Springer (see figure 1). As well as finding they shared a first name, there were more surprises in store. Each of them was exactly six feet tall and weighed 108 pounds. Both bit their nails and suffered from migraines. They both had little aptitude for spelling but were skilled in maths and carpentry. More extraordinary, they had each been married twice, first to a woman named Linda and then to a woman named Betty. One had named his firstborn child James Alan, and the other had named his James Allen. Each had once owned a dog named Toy. They drove the same model and colour of car, went to the same beach in Florida for their vacations, and shared a taste for the same brands of beer and cigarettes. ${ }^{1}$

The story of the Jim twins is one of the most famous accounts of identical twins and the uncanny characteristics they can sometimes share, even when raised apart. Their experiences also led to one of the world's biggest studies of identical twins ever, the Minnesota Study of Twins Reared Apart (MISTRA). ${ }^{2}$ To the surprise of most psychologists at the time, it showed that monozygotic twins reared apart are broadly speaking as similar to each other as those raised together-in terms of personality, temperament, occupation, leisure-time interests and social attitudes. In other words, whatever environment children are placed in, the influence of their genes usually remains predominant. The findings of the study also supported the idea that genes may lead a child to seek, or try to create, a suitable environment to fit its own abilities, rather than being primarily moulded by the environment itself. This could account for some of the more complex similarities between the two Jims, as opposed to straightforward factors like height that would have been purely genetic, or others like their particular choice of cigarettes and cars, where local cultural preferences or sheer coincidence may have played a dominant part.

Correspondence to Dr John Launer, Associate Editor, Postgraduate Medical Journal, London WC1H 9JP, UK; johnlauner@aol.com
The MISTRA study has contributed a great deal to our understanding of the relative influence of genes, the environment and the interaction between these in turning each of us into who we are. As the researchers pointed out, this does not detract from the importance of parenting or education in nurturing the best of children's innate strengths, or in helping them adapt to their vulnerabilities. Yet, along with many similar studies, ${ }^{3}$ it significantly debunked an assumption that held sway for much of the last century, namely that every child was essentially a blank slate on which anything might or might not be inscribed.

\section{ETHICAL ABUSES}

While some of the research into whether nature or nurture predominates in humans was enlightening, some of it also had its dark side. Quite how dark this became was revealed recently in a television documentary entitled 'Three identical strangers'. ${ }^{4}$ It tells the story of three New Yorkers called Bobby, Eddy and David, and is even more dramatic than the tale of the Jim twins. In 1980, when Bobby Saffran was 19, he enrolled at a community college where a student called Eddy Galland had dropped out the previous year. To his astonishment, people greeted him with Eddy's name and expressed delight that he had changed his mind about leaving college. Bobby had no idea who Eddy was, but immediately found out that, like himself,

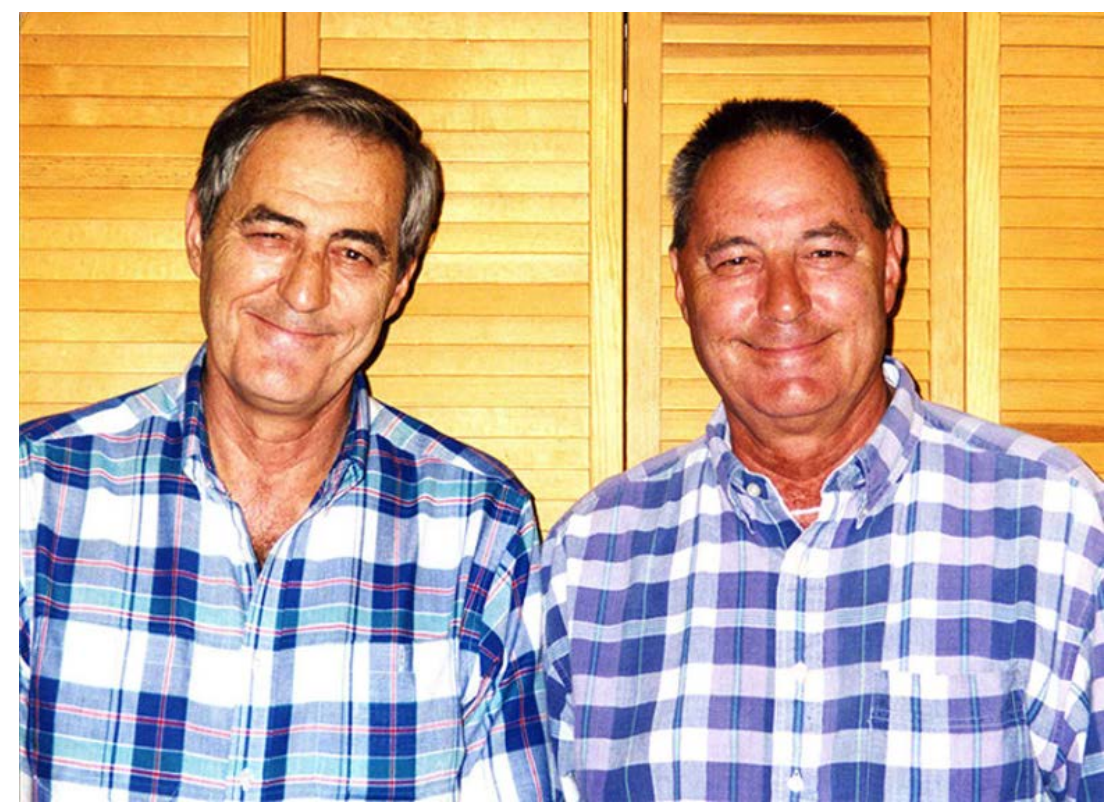

Figure 1 The Jim twins. Courtesy of the Jim twins and Dr. Nancy L. Segal each other's existence (see figure 2). eagerly collaborated.
Eddy had been adopted, and they had the same birthday. By the same evening, they arranged to meet each other and realised they must be identical twin brothers. A few months later, the story and a photo of them appeared in the New York state press. Another 19-year-old called David Kellman contacted them to let them know he had the same history of adoption, the same date of birth and the same face. Quite simply, they were identical triplets who were unaware of

Their families began to investigate what had happened, starting with their adoption agency. It turned out that, as babies, the three were among the victims-there is no other word-of a psychological experiment designed to separate five pairs of identical twins and one set of identical triplets, whose single mothers were unable to cope with them, and who had requested (or been persuaded to request) that their newborn children should be adopted. Each of the individual twins in the experiment, along with the separated triplets, was assigned to a different couple with certain characteristics regarding age, socioeconomic status, educational level, religion, and older siblings' gender and age. The aim of the research was to establish the effects of each of these characteristics, and of the couples' psychological makeup, on the development of their adoptive children. The experiment was led by two eminent New York psychiatrists, Viola Bernard and Peter Neubauer. They believed that placements with different types of couples would make it easier to tease out the different effects of nature and nurture. The adoption agency 
Staggeringly, the adoptive parents were never told the purpose of the experiment, nor even informed that the babies they adopted had been born as twins or triplets and then separated. They were simply advised that a team of psychologists would see their adopted children regularly over the coming years for physical examination and psychological testing in order to track their progress following adoption. The members of the research team were all sworn to secrecy, so that they all visited the parents and children over many years without ever revealing that they were aware of their experimental counterparts.

\section{PROFOUNDLY DISTURBING}

'Three identical strangers' is by turns inspiring, heart-breaking and profoundly disturbing. One of the three brothers, Eddy, took his own life in 1995 but Bobby and David, now in their late 50s, speak with extraordinary openness about their elation at meeting each other, the passionate friendship and shared restaurant business the three developed together, and also the immense distress brought about by discovering the deceit to which they and their loved ones had fallen prey. They describe how their adoptive parents had once arranged a meeting with the adoption agency and the lead researchers in an attempt to confront them, but got nowhere. The parents left frustrated and angry, but Robert's father had forgotten his umbrella. "He went back to get it", says his stepmother in the movie, "and he walked into the room to see everyone breaking open a bottle of champagne and toasting each other, as if they had dodged a bullet".

Doctors and psychologists do not come out well from the documentary or from articles giving accounts of these events. ${ }^{5}{ }^{6}$ Both the lead psychiatrists continued to the end of their lives to defend the research and the way it was conducted. They claimed it was consistent with the prevailing ideas of the time: a belief that twins and triplets would thrive more if raised individually, and an ethical stance that valued discretion over disclosure. Their actions, however, suggest that their consciences may not have been quite so clear. Viola Bernard died in 2004 but her archive, including correspondence with the adoption agency, has been sealed until 2021. Thousands of pages of data from the research have been deposited with Yale University, embargoed until 2066. (There is an ongoing legal battle to release some of the findings to the surviving subjects, most of whom have now discovered each other in various ways.) In spite of the study being one of the major research projects of his career,

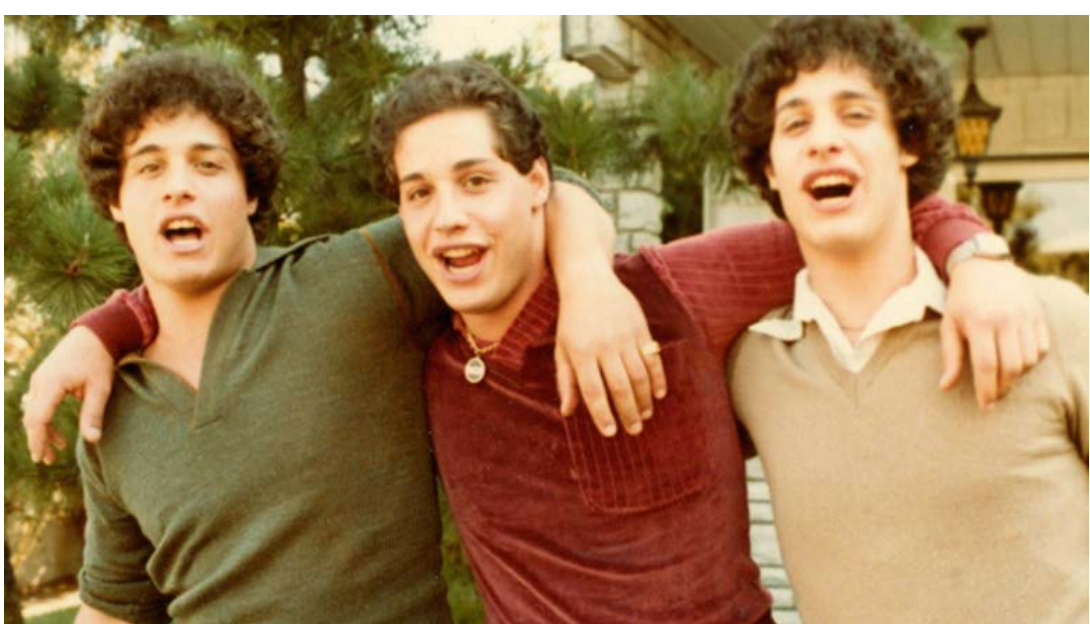

Figure 2 Eddy Galland, David Kellman, Bobby Shaffran. Neon Films.

Peter Neubauer never published a single paper based on the data before his death in 2008, although he used some case examples of separated twins in a book written with his son in 1990 and these are highly likely to be from the study. Chillingly, he reveals in one of them that he and the research team seem to have maintained secrecy even when a child's health was at risk:

Two otherwise healthy twins, living apart, began having convulsions. The pediatrician of one of these twins responded by treating the source as an infection ... whereas the pediatrician of the other twin considered a brain disorder ... If each pediatrician had known that his patient's convulsions were shared by an identical twin, they might have approached the condition differently, with a strong suspicion of genetic influence. ${ }^{7}$

The only professional who comes out of the story with some dignity is a psychologist named Lawrence Perlman, who worked on the research team during 1968-1969. He appears in the documentary and has also written frankly about his role in in the study and the reasons why he left it. ${ }^{5}$ These included poor science, disorganisation and a lack of supervision. He has also given an account of a meeting he arranged with Neubauer many years later to question him about the study. He describes Neubauer, then in his 90s, as 'gracious and charming to a fault' but 'blind to the potential ethical issues posed by separating these twins and maintaining secrecy about their twinship for so many years'.

It is a dismal judgement, but probably a fair one even by the standards of the 1960s. ${ }^{8}$ Which person alive, then or now, would not want to know if they had identical DNA to someone else, and to share their experiences as well? For Jim Lewis and Jim Springer, and also for surviving triplets David Kellman and
Bobby Shaffran, meeting each other helped them gain more understanding of themselves than they could possibly have imagined.

\section{Twitter John Launer @JohnLauner}

Funding The authors have not declared a specific grant for this research from any funding agency in the public, commercial or not-for-profit sectors.

Competing interests None declared.

Patient consent for publication Not required.

Provenance and peer review Not commissioned; internally peer reviewed.

(C) Author(s) (or their employer(s)) 2020. No commercial re-use. See rights and permissions. Published by BMJ.

$$
\text { A) Check for updates }
$$

To cite Launer J. Postgrad Med J 2020;96:59-60.

Postgrad Med J 2020;96:59-60.

doi:10.1136/postgradmedj-2019-137194

\section{REFERENCES}

1 Segal N. Born together reared apart: the landmark Minnesota twin study. Cambridge MA: Harvard University Press, 2012

2 Bouchard TJ, Lykken DT, McGue M, et al. Sources of human psychological differences: the Minnesota study of twins reared apart. Science 1990;250:223-8.

3 Wright L. Twins: genes, environment and the mystery of identity. London: Weidenfeld and Nicholson, 1997.

4 Three identical strangers (movie). Available: https:// www.threeidenticalstrangers.co.uk/home/ [Accessed 26 Sep 2019]

5 Perlman LM, Segal NL. Memories of the child development center study of adopted monozygotic twins reared apart: an unfulfilled promise. Twin Res Hum Genet 2005;8:271-81.

6 Segal NL. Commentary: more thoughts on the child development center twin study. Twin Res Hum Genetics 2005:8:276-81.

7 Neubauer PB, Neubauer A. Nature's Thumbprint: the new genetics of personality. 65. New York NY: Columbia University Press, 1990.

8 Lerner BH. 'Three identical strangers': the high cost of experimentation without ethics, 2018. Available: https:// www.washingtonpost.com/outlook/2019/01/27/threeidentical-strangers-high-cost-experimentation-withoutethics/ [Accessed 26 Sept 2019]. 